\title{
Preservation of soft tissues in an Ordovician linguloid brachiopod from China
}

Andrzej Baliński and Yuanlin Sun

Acta Palaeontologica Polonica 58 (1), 2013: 115-120 doi: http://dx.doi.org/10.4202/app.2012.0088

The findings of preserved soft body parts including pedicle in the linguloid brachiopods are extremely rare in the fossil record of which the early Cambrian Chengjiang (southern China) and Burgess Shale (British Columbia) faunas are the most important. However, these characteristic Cambrian soft-bodied faunas largely disappeared from the fossil record well before the end of the Cambrian. Here we describe the first record of the pedicle in a linguloid brachiopod from the post-Cambrian strata, preserved with remarkable fidelity. Contrary to the Chengjiang and Burgess Shale-type faunas which are commonly preserved as essentially two-dimensional aluminosilicate or degraded organic carbon films or pyritized compressed fossils, the specimens now recovered from the Ordovician of China show a three-dimensional, pyritized pedicle with preserved external morphology, in detail. The presence of streamlined shell shape and burrowing shell sculpture in our specimens supports an assumption for infaunal mode of life of the genus. Since all linguloid brachiopods of the early Cambrian are interpreted as epifaunal or semi-infaunal, it seems that the here described Ordovician linguloid is the oldest representative of fully infaunal brachiopods. Apparently, the long vermiform and flexible linguloid pedicle has appeared as a functionally optimized construction.

Andrzej Baliński [balinski@twarda.pan.pl], Instytut Paleobiologii PAN, Twarda 51/55, PL-00-818 Warszawa, Poland; Yuanlin Sun [ylsun@ pku.edu.cn], Key Laboratory of Orogenic Belts and Crustal Evolution, School of Earth and Space Sciences, Peking University, Beijing 100871, China.

This is an open-access article distributed under the terms of the Creative Commons Attribution License (for details please see creativecommons.org), which permits unrestricted use, distribution, and reproduction in any medium, provided the original author and source are credited. 
Fof Full text $(657.9 \mathrm{kB})$ 